\title{
correspondence
}

\section{Czech persecution}

SIR, - I wish to raise some points about Professor Burhop's letter (November 22). Does he know about the existence of a law in Czechoslovakia, which is much more iniquitous than the one which may be accepted in West Germany? This is the Labour Code (law 42/1970), which contains section 46, lett. e, according to which a notice could be given to anyone who "vioates the socialist social order". In the past five or six years tens (if not hundreds) of thousands of Czechoslovak citizens have lost jobs not only at schools, universities and justice offices, but also in the research institutes, mass media, theatres, publishing houses, museums, state administrative departments and so on because of the application of this paragraph.

Having been dismissed myself from the Nuclear Research Institute in 1970 under this paragraph, I tried to get revocation of my notice through the law. I shall quote here from the decision of the Court of Appeal, the highest authority in such cases:

"The claimant's activity was violating the socialist social order ... as he signed a resolution .. . which demanded a change in the system of the leading organs (of the Academy) ... Furthermore, the claimant tried to damage the development of educational and cultural policy of our state, which is led and directed by principles of Marxist-Leninist ideology, and this he did for instance... when he pleaded for the abolition of censorship of scientific publications."

Does the World Federation of Scientific Workers raise its voice against this law, which has been in force in Czechoslovakia for many years?

Professor Burhop's version of the shameful persecution of Malek is incorrect. Section 11 of the Czechoslovak pension law states that "persons who have reached the age of at least 60 enjoy a right to be retired". No obligatory retirement age is given in the law about the Czechoslovak Academy of Sciences $(54 / 1963)$.

Professor Malek's contract with the academy had not been extended in October 1973, and Malek had either to find a new job or to retire (in 1970, as a measurc of political persecution, the time limited labour contracts had been introduced in the Czechoslovak Academy of Sciences-...20, 4, law 26/1970-for senior scientists only. The duration of contracts ranges from three months to four years). This dismissal has been an act of purely political persecution or even revenge. In contradiction with world academic habits, he does not enjoy the right to keep his office or laboratory in his former institute; he is now not even allowed to use the institute library.

I agree completely with Burhop's statement that issues like the retirement age should be "matters for the people of that country to decide". Is he not aware of the fact that the people of my country lost the right to decide on their own fate on August 21, 1968, when our country was invaded by foreign troops which were occupying my homeland?

The plight of Czechoslovak scholars and intellectuals is a direct consequence of this. One should not forget it.

\section{Copenhagen, Denmark}

F. JANOUCH

SIR, - I would like to comment on the discussion between Professors Janouch and Burhop (August 9 and September 20) concerning the situation of scientific workers in Czechoslovakia.

I absolutely agree with Janouch that "only open, public stands, protests and statements are meaningful and helpful". This is not only based on my own experience while living under this regime but also on experience during work with other institutions, such as Amnesty International. There is no doubt that the procedure suggested by Burhop might be effective with some regimes which respect-at least to some extent-reasonably open discussion. This is, however, certainly not the case in the so-called people's democracies, where the hypocritical Party bureaucrats not only suppress any sort of criticism but do not even respecit their own constitutions and laws.

To illustrate the absurdity of the present situation of scientists in Czechoslovakia, I would like to bring up one flagrant example concerning Mr Karel Kriz, a former senior lecturer at the Technical University at Brno (Moravia). Like many of his colleagues, he was dismissed from his position because he declined to accept the Russian occupation as brotherly help. For some time he was not able to find any reasonable employment; in 1972, however, he started a "new career" as a buyer dealing in rabbit skins for the national enterprise KARA. Since this job was not very well paid, he was compelled to organise his business using (for Czechoslovakia) new commercial methods: he sent various posters and information leaflets (on the eminent importance of rabbit skins for the national economy and so on) to all villages in the southern part of Moravia and informed the inhabitants of his impending arrival. In fact, he organised a group of gypsies, who regularly visited all villages and bought up rabbit skins for him and therefore for KARA. One of his posters read:

Dear friends.

KARA purchases hides and skins of every description. I shall be calling at your village once a fortnight. Kindly have your goods ready for me.

Thank you for your cooperation.

Your skin buyer.

Independent scientific worker

Doc.Ing. Karel Kriz, Candidate of Sciences, skin buyer for KARA, national enterprise.

His action soon became a great success, and the gypsies, villagers and KARA were exceedingly satisfied. Even the Party bureaucrats paid tribute to the successful gypsy brigade, which was soon accepted as one of the best "brigades of socialistic labour".

The disaster came in the summer of 1973 in the form of a panel discussion on Austrian Television devoted to the brain drain. At the end of the discussion, in which the Prime Minister, Dr Bruno Kreisky, also took part, the commentator said (ironically) that some neighbouring countries had succeeded in solving this problem better than Austria had. At the same time he showed Mr Kriz's poster.

Two days after the panel discussion, Mr Kriz was arrested on a charge of damaging the interests of the Republic, according to Section 112 of the Penal Code " A Czechoslovak citizen... who damages the interests of the Republic by spreading or enabling to spread in other countries false reports about conditions in the Republic ... will be punished with prison up to three years..."). The first trial, which should have taken place in November 1973, was postponed, and in the autumn of $1974 \mathrm{Mr} \mathrm{Kriz}$ was sentenced to three years in prison, the maximum punishment. What for? After all, the text of the posters was 